\author{
Maša Kolanović \\ Department of Croatian Studies, Faculty of Humanities and Social Sciences, \\ University of Zagreb \\ Zagreb \\ mkolanov@ffzg.hr
}

\title{
The Transformation of Economic Imagery in Croatian Culture in the 1990s
}

\begin{abstract}
The article problematizes the relationship between culture and capitalism in creating a specific economic imagery of the 1990s in the Croatian cultural space as part of the post-Yugoslav context. One of the assumptions in analysing the connection between economics, culture and literature is that different political and economic systems (such as socialism or capitalism) always represent a certain type of culture. It is necessary to have a certain type of culture that will introduce and legitimize certain political and economic systems, which inevitably means that at the same time, certain types of cultural practices will also appear that will challenge and question them. The analysis detects processes of intellectual dismantling and transformation of socialism and creating the foundation for a new "moral and affective economy" (Ahmed, Bowles) of capitalism on post-socialist terrain. The author focuses on three "cultural patterns" (Williams) from the sphere of consumer culture, everyday life, scientific, artistic and cultural literature, through which she follows symptomatic traces of creating, negotiating and opposing the hegemonic culture in early 1990s Croatia.
\end{abstract}

Keywords: capitalism, socialism, economy, culture, Croatia.

This is an Open Access article distributed under the terms of the Creative Commons Attribution 3.0 PL License (creativecommons.org/licenses/by/3.0/pl/), which permits redistribution, commercial and non-commercial, provided that the article is properly cited. ( The Author(s), 2019.

Publisher: Institute of Slavic Studies, Polish Academy of Sciences

Editor-in-chief: Jolanta Sujecka

Conception and academic editing of this issue: Katarzyna Roman-Rawska, Tomasz Rawski 


\section{The Slow Rise of Capitalism in the 1990s}

T Then we try to detect the dominant line of cultural memory of the early 1990s on the territory of the former Yugoslavia, as found in, for example, memoirs, testimonials, fictional prose $^{1}$ or monographs from the perspectives of various disciplines ${ }^{2}$, we can easily claim that themes of social and political transition marked by war and ethnic conflict prevail. In the countries formed after the collapse of Yugoslavia, the 1990s have been dominantly interpreted through the prism of the first wave of political transition, after which the so-called "delayed cultural transition" (cf. D. Duda, 2005; Prica, 2004) ensued in the 2000s when capitalism revealed its true face. Although the practices of privatization of social ownership had begun even before the 2000s, culture and everyday life became visibly, or at least more visibly, transformed by the new practices and rituals of consumerism and with the arrival of a greater inflow of foreign capital into the region (see Horvat \& Štiks, 2015; Erdei, 2012). What usually goes undetected when we talk about the 1990s, especially about the first half of the decade, are the cultural practices of inauguration, naturalization and domestication of capitalism in the states formed after the collapse of Yugoslavia, or to be more precise, the (re-)entry of so-called "old-school" capitalism ${ }^{3}$ into the regional transition space, as Branko Horvat interpreted the "regression of [socialist self-management] into predatory capitalism of the Yugoslav monarchy" (Horvat according to Cvek, 2017, p. 115). In this paper, I will try to outline the local flavour of slowly developing capitalism within the limited cultural terrain of Croatian culture in the early 1990s, with the aim of better understanding its specificities not only as a new economic system, but also a new system of affects and values in the local environment. Namely, when speaking about capitalism in the context of Croatian post-socialist culture, we must be aware of its historical, spatial, and even local specificities in order

\footnotetext{
1 A more detailed reference to literary texts that address the war and its aftermath would take us away from the proposed focus, since it is almost impossible to find an example of literary fiction from the 1990s and later which does not contain motifs of war and its aftermath at least to some degree.

2 For example Baker, 2010; Čale-Feldman, Prica, \& Senjković, 1993; Matić, 2014; Povrzanović \& Jambrešić Kirin, 1996; Senjković, 2002 et al.

3 I use the term "old-school capitalism" in reference to the film The Old School of Capitalism (Stara škola kapitalizma) by Želimir Žilnik (2009). A related term would be "turbo-capitalism" in the sense of unbridled capitalism which intensifies economic insecurity and social tensions, as proposed by Edward Luttwak (1999) in his book Turbo-Capitalism: Winners and Losers in the Global Economy.
} 
to avoid the danger that lies in general and somewhat inflationary use of the term in cultural analysis. Cultural geographer Nigel Thrift claims:

It is not as if the proponents of the cultural turn do not acknowledge the importance of something called capitalism. They do, usually in one of three ways. First, capitalism can be generalized out to an all-pervasive cultural formation, usually through its migration into the symbolic realm. Second, capitalism can be elevated into something so self-evident that it can be trundled on whenever a connective explanation is called for. Third, capitalism becomes a reading. It can then be made into a transcendental haunting, both everywhere and nowhere. (Thrift, 1999, p. 135)

Referring to Meghan Morris, Thrift concludes that "the force of capitalism is acknowledged but it is turned into a necessary but empty foil for the cultural turn, included certainly, but allowed no life of its own, because it is always already accounted for" (Thrift, 1999, p. 135). In this regard, I believe we should focus on the temporal and sociocultural level of the early transition period in Croatia, in order not to speak about capitalism as a kind of "transcendental spectre" (Thrift, 1999, p. 135) so as not to "get its hands dirty in the kitchens of empirical research" (Bourdieu according to Bennett, 2005, pp. 48, 49). The rediscovering of capitalism in the transition from communism to capitalism surpasses strictly economic parameters and is deeply connected with culture, its texts and practices in the widest sense of the term. In this paper I start from the assumption that capitalism (as well as socialism or any other system) is not only an economic, ideological and political system, but also a certain type of culture. For a system to be possible, realized and made legitimate, a certain type of culture is needed which will introduce and legitimize it, and this in turn means that types of cultural practices which will challenge and contest it will always arise. My tentative thesis, or better yet observation, is that parallel to the processes of war, ethnic conflict, the strengthening of separate national identities and the collapse of socialism, hard-core (or, according to Žilnik, old-school) capitalism was developing not only in terms of the basic economic processes of transformation and privatization (see Gregurek, 2001) , $^{4}$ but also in the field of culture, understood in its broadest definition as "a whole way of life" (R. Williams, 1997). The period of the early 1990s in Croatia represents a challenging, or more precisely, a unique cultural and anthropological field for considering local and temporal specificities of the capitalism which has emerged from the ruins of socialist Yugoslavia, and I believe that this layer of the period is still insufficiently researched, primarily because of sociotraumatic problems of the war that dominate not only the social but also

4 Important notions and insights about these processes are also contained in Gajin, 2018; Ivanković \& Šonje, 2011 and Sekulić, 2016. 
the analytical imagery of that period, to which this layer does not stand in opposition. ${ }^{5}$

When we speak about capitalism in the 1990s, we should start from the fact that Yugoslavia already had certain economic practices that occasionally approached capitalism, as an untypical and "somewhat eccentric member of the family of socialist systems" (Hobsbawm, 2004, p. 302). Even though the story of the Yugoslav variant of capitalism could lead us into a very lengthy discussion (see, for example, Archer, Duda, \& Stubbs, 2016; Dimitrijević, 2016; I. Duda, 2005, 2010; Jakovina, 2002; Jelača, Kolanović, \& Lugarić, 2017; Patterson, 2011; Rusinow, 1977; Suvin, 2016), in this chapter I talk about Yugoslavia as a country that built its political, economic and cultural identity at the crossroads of the capitalist West and the socialist East. However, this "cultural life of capitalism in Yugoslavia" (Jelača et al., 2017) was qualitatively different from the one we encounter after the break-up of Yugoslavia, and these should not be equated lightly, despite the fact that they could be compared in many ways. In this paper, I will try to address some specificities of the "cultural life of capitalism" of the early 1990s in Croatia by taking several "patterns of culture" which I find symptomatic for the creation of a new "structure of feeling" in Croatia in the early 1990s. The term "patterns of culture" comes from Williams' text "The Analysis of Culture" (R. Williams, 2006, pp. 39-40), where he interprets it as follows:

... it is with the discovery of patterns of a characteristic kind that any useful cultural analysis begins, and it is with the relationships between these patterns, which sometimes reveal unexpected identities and correspondences in hitherto separately considered activities, sometimes again reveal discontinuities of an unexpected kind, that general cultural analysis is concerned.

... The "pattern of culture" is a selection and configuration of interests and activities, and a particular valuation of them, producing a distinct organization, a "way of life".

The patterns of culture selected for this analysis will include, as Williams points out, "hitherto separately considered activities" as a network in the sense of a wider picture of a specific capitalist system of values and affects, and in this case these will be printed advertisements and translated foreign

\footnotetext{
Of course, there are exceptions that have seen this connection at different levels. For example, Ante Lešaja wrote about the economic contextualization of the birth of Croatian nationalism in the early 1990s in his extensive book Knjigocid: uništavanje knjiga u Hrvatskoj 1990-ih (Bookocide: Mass Destruction of Books in Croatia in the 1990s) (Lešaja, 2012).

6 The term "structure of feeling" as an analytical concept is taken from theoretician Raymond Williams (R. Williams, 2006, p. 41), who in his text "The Analysis of Culture" interprets it as follows: "... it is as firm and definite as 'structure' suggests, yet it operates in the most delicate and least tangible parts of our activity. In one sense, this structure of feeling is the culture of a period: it is the particular living result of all the elements in the general organization".
} 
literature from the field of economics and social thought in Croatia in the early 1990s. In the pattern of culture of printed ads, I will look at this genre of consumer culture as the first heralds of these new sensibilities. Advertisements included in the analysis are a representative sample from the sphere of everyday life, which underwent changes through the practices and rituals of consumer culture which captured and shaped the social imagery together with war propaganda and reports on the course of the war. In the second pattern of culture I will include a selection from foreign literature in the field of economics and social sciences as a symptom of theoretical movements in the discussion on capitalism that marked the transformation of intellectual consciousness due to major social, political and economic changes. In these discussions, apart from new theoretical views on the fundamental features of capitalism, the subject of the selected literature is often socialism and the "new reading" of it which takes place during the collapse of socialism as the social system in Eastern and South-East Europe. Finally, in the third pattern of culture that covers texts which deviated from the official line of thought in Croatia in the early 1990s, I will try to offer a possible new focus in their reading. Namely, these texts have thus far been interpreted primarily as a critique of nationalism, but there is also a very important layer of critique of capitalist practices, particularly in the layer regarding the social and cultural imagery of the West, often embodied by the United States as the country with the greatest utopian potential when it comes to how capitalism is imagined. Generally speaking, all these layers have a common framework in the sense that they are involved in the creation of a new "structure of feeling" or that they comment on it, and all of this takes place during the war and the collapse of socialism on the territory of the former Yugoslavia. With this selection, I will try to address the complex field of culture that co-created, naturalized, and questioned the rediscovery of capitalism in the early phase of transition in Croatia.

But capitalism will not be seen here only as a new "structure of feeling" that is to be detected and described. It will be seen as a force that also structures feelings. Indeed, post-socialism is not only a challenging field in terms of social, political and economic transformation, but it is also a highly dynamic field of great transformation of sensibilities. As cultural anthropologist Maruška Svašek claims in the introduction to Postsocialism: Politics and Emotions in Central and Eastern Europe, political processes necessarily carry specific emotional value. Problems of transition and postsocialism are usually discussed in the economic, political and social contexts, but little attention is given to their emotional dynamics (Svašek, 2006, p. 2). In a draft of one such anthropology of emotions of post-socialist Europe, Svašek, similarly to Scribner (2003) in the field of art, speaks about different 
types of emotions in everyday life, whose tonality ranges from hope and euphoria to disappointment, envy, disillusionment, regret, loneliness and hatred. In that light, suffice it to recall the iconic images of chronotopes in Eastern and South-East Europe from the late 1980s and early 1990s: from the euphoria of the people on the ruins of the Berlin Wall, the open desire for material abundance that capitalism would bring, to the despair, the misery and the humiliation of the people in the ruins in Yugoslavia which were not only metaphorical. The changes in the social, political and economic fields ${ }^{7}$ were accompanied by strong affects associated with specific values, standards and principles that we might call new sensibilities and a new morality. In all this, culture is not only a representation, but also an active creation of a new moral and emotional economy of capitalism in terms of the social relationship of the community and individuals towards capitalism, and thus indirectly towards socialism which, as I shall show, closely follows the reflection of capitalism in the early 1990s. In this light, the notions of moral and emotional economy imply here a complex relationship among economic practices, culture, tradition, legal regulations, and the ethics of each individual as well as the circulation of affects among individuals.

\section{Affects, Morality, Economics and Culture}

I will observe affects and morality here as entities which are configured in their profound connection with economics. The connection between affects and morality, and economic processes is primarily concerned with "human" problems of economics, and not just economic problems of people, which are usually discussed when talking about economics. It was precisely the global economic crisis of 2008 that exposed the moral and emotional components of economics as a practice on the one hand, and on the other economics as a science which is often epistemologically unequipped to explain this complex connection with culture and human existence. ${ }^{8}$

I differentiate between affects and emotions according to the degree of their social expression, following the elaboration of Sara Ahmed (2004).

I use the term field according to sociologist Pierre Bourdieu (1993, p. 162), who defined it as a relatively independent social universe with its own laws of functioning. Although it is an autonomous social universe (for example, the field of art, science, literature, religion, philosophy, politics, law, economy, etc.), the field functions as a prism in which rays of all external determinants refract, so in this sense demographic, economic and political events are always reinterpreted in relation to the specific logic of the field (Bourdieu, 1993, p. 164).

8 See the recently published study Cents and Sensibility: What Economics Can Learn from the Humanities (Morson \& Schapiro, 2017) for the shortcomings of economics as a science and why it requires the humanities for a more comprehensive understanding of human conditions of material life. 
She showed that emotions are never static, solely related to individual subjectivity or of an exclusively private and psychic nature. Since they have to circulate among individuals to be recognized as emotions, they are part of the domain of sociality by their very nature. Ahmed thus observes and interprets emotions through the economic concepts of circulation and exchange, which gives us grounds to apply this concept to the chronotope of the 1990s in Croatia when affects were associated with social and economic concepts to a greater degree than ever before or since. Moreover, in order for these changes to be possible and real, it was necessary to mobilize affects on a much wider level than that of an individual. According to Brian Massumi, affects can produce economic effects much faster and in a much safer way than the economy itself. Affects are, Massumi goes on to claim, "an intrinsic variable of the late-capitalist system, as infrastructural as a factory" (Massumi according to Richard \& Rudnyckyj, 2009, p. 72). In this case, affects are closely related to capitalism not only as an economic but also as a specific value system. ${ }^{9}$ Capitalism, with all its specificities at the economic level (such as the free market and capital management by capitalists, which is part of the textbook definition of capitalism as an economic system), is also a specific system of values, such as competitiveness, competition, private and entrepreneurial initiative, flexibility, risk acceptance, etc., which spread to principles such as the attachment of monetary value to all social and cultural configurations, etc. Such a new moral economy is by its character and configuration significantly different from the official economy of socialism ${ }^{10}$ and represents a more explicit and radical form of capitalism, even in reference to the Yugoslav version of so-called market socialism. ${ }^{11}$

\footnotetext{
9 Economist Joseph Schumpeter wrote about this in the first half of the 20th century, claiming: "Capitalism does not merely mean that the housewife may influence production by her choice between peas and beans; or that the youngster may choose whether he wants to work in a factory or on a farm ... it means a scheme of values, an attitude toward life, a civilization of inequality and of the family fortune" (Schumpeter according to Bowles \& Edwards, 1991, p. 26).

10 For example, values such as solidarity, social distribution of goods, social security, etc., and their associated affects.

11 Even though the concept of economics in its Aristotelian definition implies morality, as Norbert Götz (2015) explains, the term appeared when morality was separated from the notion of economics in the mid-18th century. Since then the link between economics and morality has no longer been so obvious. Moreover, people often speak of the demoralization of economic relations which is today normally linked to neoliberalism (see Banks, 2006, p. 456). The study "The Moral Economy of the English Crowd in the Eighteenth Century" by British Marxist historian Edward Palmer Thompson about food shortages in 18th-century England during the transition from the traditional into the modern social and economic system is often referred to as bringing about this specific branch of economics which is also spreading to activism. Since the 1970s when E. P. Thompson published his study, the connection of values and feelings with economic choices has stood in the centre of the theorem of a moral economy (Daston according to Götz, 2015), and this theorem owes its philosophical background to Marx. Thompson's study provided
} 
The arrival of the free market, to paraphrase Samuel Bowles, teaches people how to accept new kinds of motivation and to reject the old ones (cf. Bowles, 2016, p. 205), and this is precisely what was happening during the observed chronotope. Learning new social norms is key for the functioning of the market and for accepting capitalism as a specific value. In all this, culture has an important and even key role. Culture is not just a superstructure or a reflection of what is happening in the seemingly more important layers of society. It participates in the anticipation of these changes, it has the role of an agent and a catalyst, and it quite often challenges their implementation. This connection between the economy and culture is particularly apparent in transformative processes such as the collapse of one and the creation of another economic system, for which Croatia in the 1990s offers almost ideal research conditions.

\section{Advertisements in the 1990s: Heralds of New Values}

In the first pattern of culture of the "structure of feelings" of capitalism in Croatia in the early 1990s, I will focus on the advertising genre as one of the most prominent everyday aspects of consumer culture in capitalist societies. Advertising is, to refer to Fredric Jameson, a mode of aestheticization and culturation of everyday life of consumer culture in late capitalism (Jameson, 1988). It is "the idiom, the style of the culture industry" (Horkheimer \& Adorno, 1989, p. 174), "the official art of capitalist society" (R. Williams, 1999, p. 421), not to list further definitions which point to its close association with capitalism.12 Advertisements were in a way the most visible indicator of the transformation of socialist societies into capitalist societies. As Erdei puts it (Erdei, 2012, pp. 99-100):

One of the most visible features of social transformation after the collapse of the socialist world in Eastern Europe was a change of the geography of consumption.

the basis for an analysis of ethical components of the economy in terms of areas and practices of production, consumption, distribution and trade, and since then the concept of a moral economy emerges regularly as an analytical (and activist) necessity in observing the behaviour of people during major social and political transformations. This offers a good basis to apply the moral and the related affective component of economy to the chronotope of the early transition phase in Croatia.

12 Commercials are equally present in socialist societies in their fully developed form. However, it should be emphasized that although consumption as a ritual and as a practice definitely existed and was quite developed in socialism, after 1989 these societies "rediscovered consumption" (Erdei, 2008, p. 71). For more about the context of the consumer culture of socialism, see Bren \& Neuburger, 2012; Dimitrijević, 2016; I. Duda, 2005, 2010; Patterson, 2011. This article invokes the spreading of the discussion in the direction of dispositions that enabled capitalism to be embraced on affective and moral levels before the change actually happened, but considering the length of this text, I will stay focused on the topic framed here, and leave that for another occasion. 
The character of social change which was oriented towards the transformation of a predominantly planned into a liberal market economy was most striking in creating many opportunities to satisfy consumer desires and needs. Thus, the "faces" of the capital cities of the former Eastern Bloc, almost a century after the Europeanizing wave of reconstruction, were redesigned in the spirit of the principles of the latecapitalist economy's logic. Foreign brands flooded the once protected markets, huge advertising billboards appeared in the streets and at city entrances, wherever they could be placed, and symbols of capitalism, such as Coca-Cola, McDonald's and IKEA were initially embraced as a promise of a better life....

The example with which I raise the issue of culture and capitalism in the early stages of post-Yugoslav transition is connected to Coca-Cola, a brand which has become a symbol of capitalism in the global cultural consciousness (see Elmore, 2014; Vučetić, 2012) and is closely related to the imagery of the United States or America as a "conceptual metaphor" (Lakoff \& Johnson, 2003) of material prosperity or a "better life", as written by Erdei. Namely, thinking, building and practising capitalism does not take place solely in the social strata which are seemingly more important than culture. These processes are often metaphorical in nature, with culture playing an important role. Capitalism is always imagined, to use the wording of Lakoff and Johnson (2003, p. 58), through “... a particular set of cultural assumptions", where that concrete concept is used to understand an abstract concept, which in this case means that the West and often America are used to understand capitalism - and this was also true in the socialist period. Two Coca-Cola commercials which I will present here concern the socialist and post-socialist period, and I use them to illustrate the nuances of the "cultural life of capitalism" in the socialist and post-socialist era. ${ }^{13}$

Both of these examples are not Coca-Cola commercials in the narrow sense of an explicit imperative which calls for buying and consuming the product, but can be seen as advertisements which indirectly advertise the corporation, but have distinctive features with wider value implications. The first example is Coca-Cola acknowledging the Day of the Uprising of the People of Croatia on 27 July 1977, a holiday on which the corporation congratulated the people of Yugoslavia through Radničke novine (Worker's Newspaper). Although this message of congratulations was not an explicit

\footnotetext{
13 Regarding the selection of these two ads, I would like to point out that I am fully aware of the problems in choosing these two somewhat extreme examples. But such a choice was prompted by the observation that the advertisement/commercial which I list as an example for the socialist period and the set of values which were invoked could not be found in the transition period, and that a commercial from the transition period could not be found in socialism. Naturally one could find various degrees between these two extremes, but these have been chosen as radically different examples in order to address the change in the qualitative dimensions of the moral and affective economy of socialism and the transition period.
} 
invitation to purchase and consume the product, it can still be seen as an advertisement because any appearance of a corporate logo in the public sphere is an indirect way of advertising. Furthermore, we know very well that in modern culture, leisure and social and religious rituals have become symbolic spaces dominantly articulated by spending, especially when it comes to this multinational brand that has virtually become synonymous with holidays, especially at Christmastime (see Whiteley, 2008). However, in this example from late socialism, it is a socialist, or more precisely an anti-fascist holiday on which Coca-Cola is congratulating the workers and citizens of Yugoslavia. In that congratulatory advertisement with minimalist design, the Coca-Cola logo takes up just under half the space, while the other part is composed of a text saying "Coca-Coca and the Coca-Cola bottlers in Belgrade, Zagreb, Sarajevo, Lipljan and Žalec congratulate all the workers and citizens of SR Croatia on 27 July, the Day of the Uprising" (according to I. Duda, 2010, p. 22). Even a superficial look at this ad tells us that neither its visual nor its written part has explicit consumerist imagery or an explicit consumerist imperative. No doubt, one could find other advertisements for this company in socialism, but one thing is certain, we cannot find Coca-Cola's (or anybody else's) congratulatory message for the Day of the Uprising (which is not a holiday in the independent Republic of Croatia) or any other anti-fascist holiday in advertisements of the post-socialist period, nor have the workers been singled out as a relevant social subject.

The example from the early 1990s is also not a commercial for CocaCola in the narrow sense of the word, but a sales announcement for vending machines for refrigerated drinks, dominated by the aesthetics of the CocaCola brand. The visual part of the ad shows three vending machines with the Coca-Cola logo. The ad was published in Večernji list on 9 February 1991, when Yugoslavia still nominally existed (as mentioned in the text of the ad), ${ }^{14}$ but the first armed incidents in the so-called "Log Revolution" that broke out in August 1990 on Croatian territory had already occurred. The visually more prominent written part of the message states: "Your opportunity to get rich quickly and easily". From this message alone one can infer the morality of the new "structure of feelings" that calls for quick and easy money. This "quick and easy money" fits into the general tendency of Croatian society in the early 1990s, which sociologist Josip Županov detected and described as the value of "gaining unlimited wealth" (Županov, 1995, p. 164). ${ }^{15}$ If we compare these

\footnotetext{
14 All quotes from all the ads in this paper according to Vukić, 2006. The text of the ad (Vukić, 2006, p. 264) reads: "For all information contact the exclusive representative of TECHNOMET for Yugoslavia”.

15 Županov (1995, p. 164) says the following about the comparison with the socialist period: "At the level of the individual there was a subdued value of utilitarianism and profiteering (getting
} 
two ads according to the type of their moral and affective economy, we can infer two essentially different value systems and their corresponding affects. In the first example, workers and citizens were singled out and the values of the anti-fascist struggle as the collective good of the community were promoted, and in the second one, what was promoted was individual profit through private entrepreneurial initiative. What is even more interesting in the advertisement for the distribution of vending machines for refrigerated beverages in 1991 is the imperative of being the first ("be the first") to put the machines in the "best places", which are listed in the following order: train and bus stations, schools, universities, companies, beaches, marinas, shops, department stores, hospitals, clinics" (Vukić, 2006, p. 264). This topographic list can also be observed through the social semiotics of signification, which does not refer only to specific locations, but rather to symbolic public spaces which were randomly included in privatization and commercialization during the so-called second wave of economic transition. It was important, therefore, to be "the first" in that scramble, because the moment of such an opportunity was truly unique. ${ }^{16}$

As I have already pointed out, there are certainly other examples and practices which would fall between these two extremes of the moral and affective economies of Coca-Cola ads, so we should not draw far-reaching conclusions about the moral and affective economics of advertising in socialism and post-socialism based solely on the comparison of these two ads. But the discursive novelty of encouraging people to make quick and easy money as a value is not an exception to be found only in this ad. It has more to do with the change in the broader structure which points to the differences in values embedded in the socialist and capitalist advertising strategies, as written by Erdei (2012, p. 60) when she argued that in socialism:

rich). Now, that value erupted with full strength because of the collapse of the self-management ideology and the acceptance of free economic competition. Unlimited wealth, as the main individual value, is so powerful that it also endangers the modern market economy and the moral system of society". This value co-exists with the values of utilitarianism, the "heroic code" and radical egalitarianism at other levels (national and societal) (Županov, 1995, p. 164).

16 An interesting commentary on such a practice can be found in the story Šoping (Shopping) by Robert Perišić from the 2000s, denouncing this new type of entrepreneurship in the early 1990s in Croatia. In the story, Filip, one of the "economic losers" of the transition period, makes the following comment to his partner Anela about the success of his acquaintance in the distribution of the energy drink Red Bull: “The guy is here in the neighbourhood. He's a distributor. He's fucking loaded... Because he was the first to start distributing Red Bull, ages ago. When that thing first started. He was the first to get the idea, he started his company... You fucking have to think of that, that's the thing...” (Perišić, 2002, p. 78). By stressing the need to be first as a sort of imperative for success in the new economic circumstances, legal and regulatory conditions and norms are normally absent, which speaks in favour of the new (a)moral economy of capitalism in the early 1990s. 
... Advertisements were not intended to awaken and shape desires and to create never fully satisfied consumers like in capitalist societies, but rather to create awareness about ways of rational consumption, to negate the culture of shopping and, most importantly, to improve the taste of consumers and shape their demands.

"Awakening and shaping desires" and "creating never fully satisfied consumers", as described by Erdei as a distinctive feature of advertising in capitalism, can also be seen in other advertising patterns of the 1990s, such as the advertisement page of the popular illustrated magazine Arena from April 1996, which delivers a collage of ads on loans and funeral services. The ads for the loans are also written in the advertising style promising easy and quick achievement of the desired goal, so they can be taken out "quickly, discreetly, without surety, according to your wishes, with favourable interest rates" (Vukić, 2006, p. 295), while funeral services are advertised as extremely "safe, quick and affordable" (Vukić, 2006, p. 295), so there seems to be virtually no difference between funeral services and loans.

Encouraging desire, bringing fantasy closer to reality, realizing the "magical world of dreams", achieving pleasure and material success, "quickly and easily" with minimal effort, etc., are thus discourse places that expose specific economic fantasies of the transition homo economicus supported by the advertising discourse as a specific value and affective statement. The workers disappeared from such imagery and were replaced by Croatian citizens as consumers in accordance with the Western model. The accompanying euphoria constructed by utopian images which inspire hope in the fulfilment of the produced desires stems from the new possibilities of social and economic conditions, which are not hindered by the harsh reality in, as Županov would say, "free economic competition". Even though consumption as a practice was quite present in socialism where its strategies were developed, in the 1990s we can follow consumption as a regulated practice which creates a consumer society based on the logic of consumption (cf. Bauman according to Erdei, 2012, p. 70) as its deep value and permeating structure.

\section{Economic and Social Thought: Foreign Literature and Domestic Commentaries}

After reflecting on the pattern of culture of advertising as an illustrative example from the field of consumer culture in the early 1990s, we look at the field of theoretical developments in which I also find examples indicative of processes of inauguration, naturalization and domestication of capitalism in the field of science and higher education. The already described practical everyday level and the theoretical level which I am about to expound on show 
significant concordance. This can clearly be seen from the choices made by publishers as to which foreign literature from the area of economic and social thought to translate into Croatian. These books introduced capitalism as an economic system into the domestic symbolic space, but also as a set of specific values that were vastly different from those of socialism. In detecting the symptoms of this pattern of culture, I will be less concerned with a deep analysis of the economic and sociological issues of the actual texts, and more with their value and affective statements related to capitalism and socialism, and the paratextual elements (forewords, afterwords, commentaries) that domesticated capitalism into the local context in a specific historical period. The choice of foreign literature to be translated was made according to the criterion of influence (new textbooks and professional literature that disseminated new views on the economy and society) and the creation of a new affective relation to socialism (which was dying out) and capitalism (which was on the rise), all of which represented a factual and conceptual novelty in the intellectual climate of the time.

A good example of this practice can be found in the translation of the book Understanding Capitalism by American economists Samuel Bowles and Richard Edwards published by Školska knjiga in 1991. The afterword by local editor and economist Luka Marković is illustrative of the time and place of the publication of this American textbook. He stresses that the type of economic thought practised by these authors has not only reflective value, but also "practical" value in managing the economy. At the moment when this translation was published, Yugoslavia still nominally existed, although it was already undergoing a process of political disintegration, and there was no nominal capitalism on the local terrain, i.e. it was still in the process of being created (or rediscovered, depending on one's preferences). The author of the afterword uses the past tense when speaking about socialism, and puts it in inverted commas with an added explanation that is not devoid of ambivalent affects associated with a system that was obviously disintegrating and another one that was evidently on the rise. As Marković puts it:

It can hardly make sense to reproach Bowles and Edwards, who, when speaking about the former "socialist countries", do what everyone else does, behaving as if they have reached the edge of the planet. Everything that can be learned from this book about "socialism" in Eastern Europe is: it is some different kind of class society, it is undemocratic and completely unattractive. In terms of theory, this says nothing about the regimes that functioned to the misfortune of their peoples for a good part of the century, regimes in which many people spent their whole lives (which for many were shortened, and everybody was short-changed), the regimes in which much occurred in economic terms and which represent an overwhelming empirical body to be perceived as some kind of political state of emergency which 
only happened to last a little longer, as a sort of aberration from the capitalist "normal state of affairs", which does not require any particular theoretical definition. (Marković, 1991, p. 397)

In this quote, ambivalence can be seen in the articulation of affects related to the socialist systems that functioned "to the misfortune of their peoples", but which also make an "overwhelming empirical body" to be simply overlooked. But in describing the future of the interpretation of socialism, Marković is unambiguous. The future, according to Marković, lies in the reintegration of this "overwhelming empirical body" into the general theory of capitalism as:

... one of the ways of its emergence or at least as its deviation. The creation of places where this episode of world history would merge with the general theory of capitalism will probably encourage a re-evaluation of some of the premises of that theory. This will certainly happen in the years to come, and as far as students are concerned, the best they can hope for is that their teachers will follow such literature and use it to supplement this textbook in their classes. (Marković, 1991, p. 398)

But the ambivalence of affects related to socialism and capitalism does not stop in the afterword to the local publication of this textbook. The approach of Bowles and Edwards teeters between the liberal and critical approaches to capitalism, so their own view of American capitalism could be described as ambivalent. The authors interpret capitalism as a dynamic economic system which leaves no sphere of life intact, both in positive and negative terms. In their interpretation of capitalism, the authors mention Marx, Joseph Schumpeter and John Maynard Keynes as three leading thinkers of political economy. They consider the influence of capitalism on the establishment of democracy unquestionable, the periods of recession a necessary part of the cycle of capitalist economy (Bowles \& Edwards, 1991, p. 275), and they write about socialism as an imposed form of dictatorship that is far more oppressive than the one which Marx criticized as a young journalist (Bowles \& Edwards, 1991, p. 24). Still, in trying to find a balance between the positive and negative aspects of capitalism, we can also read some unequivocal criticism of (American) capitalism, not just as an economic system but also as a value system which is less efficient, just and democratic than it could be (Bowles \& Edwards, 1991, p. 346). Despite injustice, inefficiency and lack of democracy as the values of the moral economy of capitalism in (then) contemporary America, the understanding of capitalism is, according to the authors, necessary for the understanding of our "realities" (Bowles \& Edwards, 1991, p. 13). The translation of the American textbook, accompanied by a note from the author for the Eastern European market written in February 1991, can 
thus be interpreted as a performance act of the introduction of "capitalism" as something that was becoming inevitable and almost necessary in the postYugoslav economic reality, whose transformation in the early 1990s was under way. The translation of another textbook, Economics by Nobel Laureate in economics Paul A. Samuelson, was published a year later as an important source of transmission of mainstream economic ideas. The publication of this textbook took place parallel to the dying out of one and the creation of a new political, social and economic system, so the rights to the book were acquired during Yugoslavia but the book was published in the independent Republic of Croatia, as the translators noted in a footnote (Samuelson \& Nordhaus, 1992, p. xii). The translation of this textbook was not accompanied by any comments by local editors, but the names of 33 Croatian companies (including three banks and the Zagreb Stock Exchange) were printed at the beginning of the book as those who made the publication of the textbook possible. Samuelson and Nordhaus contributed a commentary to this edition of their world-famous textbook, first published in the United States in 1948. As this edition was published in the wake of the dramatic events in Eastern Europe, the authors in their foreword interpreted the collapse of socialism primarily through the prism of economy:

... And in the most dramatic event of all, the peoples of Eastern Europe abandoned their socialist shackles and decided to try market capitalism in order to increase their standard of living. It was a triumph of the market as a way of organizing an advanced, technologically sophisticated economy. (Samuelson \& Nordhaus, 1992, p. xv)

In the case of Samuelson and Nordhaus, the conceptual metaphor of "shackles", often used for the period of socialism, was in this case primarily associated with the lack of a free market in socialism, rather than the lack of democratic and political freedom, to which this metaphor usually refers in the local Croatian context (cf. Perić, 1992). Likewise, when they address students of the former socialist countries, for whom this book was principally intended, the authors accentuate the revolution in Eastern Europe primarily for its significance for the economy, similarly to Berger and his interpretation of the revolution as a truly capitalist project. In this context, they state:

Today, the countries of Eastern Europe, the Soviet Union and elsewhere are pressed by economic revolutions - people are tearing up walls, overthrowing established authorities, and demanding a "market economy" because they are dissatisfied with their centralized socialist governments. Students like you are marching in their desire to gain the right to learn from western textbooks like this one, hoping that they will be able to experience economic growth and the standard of living of market economies. (Samuelson \& Nordhaus, 1992, p. xx) 
If these textbooks corresponded somewhat to the schizophrenic time of some sort of initial theoretical transition of economic thought towards a new order which regarded capitalism as an inevitable reality that could still be treated critically, the translation of Peter L. Berger's book The Capitalist Revolution: Fifty Propositions About Prosperity, Equality and Liberty published in Croatia in 1995 represents a much stronger performative act of domestication and legitimizing of capitalism in the post-Yugoslav space in terms of affects. The original book was published in the United States in 1986, and Croatian readers got the translation when the country had already gained its independence, with a new preface to the second edition by the author, at a time when socialism had already collapsed as a social system all over Eastern Europe. In his new preface, Berger expressed euphoria over the fall of the socialist regimes across Eastern Europe, often accompanied by complacency because his own predictions had been confirmed. In his book on capitalism, the author continues the theoretical tradition of Max Weber, Joseph A. Schumpeter and Friedrich Hayek, while he does not recognize Marxism as a scientific method of explaining capitalism (Berger, 1995, p. 5). Moreover, Berger speaks about Marxism, as well as socialism, as mythopoetic creations (Berger, 1995, pp. 5, 25), whereas he considers capitalism a much more rational system, expressing doubt that "capitalism as such would generate a myth of its own" (Berger, 1995, p. 25). Despite the moral and affective disqualification of socialism on the first few pages, the comparison of capitalism and socialism is also present in this book far beyond the preface. The author perceives socialism and capitalism as parallel manifestations of modernity (Berger, 1995, pp. 12-13), clearly making a distinction between their moral and affective economies. In his opinion, capitalism is unequivocally "the morally safer bet" (Berger, 1995, p. 13) for achieving prosperity, and its superiority according to Berger can be seen "in improving the material standards of living of large numbers of people, and ipso facto the capacity of a society to deal with those human problems amenable to public policy, notably those of poverty" (Berger, 1995, p. 19). The collapse of socialism in Eastern Europe perfectly fits the author's theses outlined in this book and in the context of its translation into Croatian at the time of institutional revisionism as the dominant relationship of post-socialist culture towards socialism in that period (see Trifonova, 2007). Such a relationship towards the practical and moral economy of socialism could be interpreted according to the claim made by Gibson-Graham (2006, p. xxxiv) in another context but which is also applicable to this case: "A project of instituting a different economy must restore this obdurate positivity to its negative grounding", which in this case means that the legitimacy of the project of a new capitalist 
economy has to be established through the negative affective and moral re-articulation of the socialist economy.

Similarly, we can interpret Berger's thoughts on the problem of poverty, which is solved by faster economic growth in capitalism and not in socialist stagnation. Just like Bowles and Edwards, he considers capitalism a necessary precondition for the establishment of democracy. In this regard he argues:

By far the most dramatic relevance of recent events to the propositions in The Capitalist Revolution is in the relation of capitalism and democracy. And here I would say, at the risk of sounding self-congratulatory, that the plausibility of two key propositions has been enhanced-to wit, that capitalism is the necessary but not sufficient condition of democracy, and that market forces in a socialist or heavily statist society have a democratizing effect. (Berger, 1995, pp. 21-22)

Berger sees capitalism euphorically as the revolutionary motor of society that keeps it moving forward to achieve progress and improvement in all aspects of life, offering the following blasphemous statement: "One might even say that the only genuine revolution under modern conditions is that of democratic capitalism" (Berger, 1995, p. 23). Berger, just like Bowles and Edwards, considers American capitalism the very definition of capitalism, with the difference that he looks at it through its almost utopian imagery of abundance, development, democracy and individualism, therefore, through extremely positive moral and affective components associated with the broader context of culture (Berger, 1995, pp. 36-37). ${ }^{17}$

Along with these texts that do not speak neutrally about capitalism, and especially not about socialism, but in such a way that they produce affects according to their social, economic and cultural specificities, I should also mention the book Poslije potopa (After the Flood) by Croatian sociologist Josip Županov, which was published the same year as the Croatian edition of Berger's book. In this book of essays, the well-known Croatian sociologist mainly deals with the topics of Yugoslav socialism and Croatian transition in the 1990s in the social, economic and cultural field. Županov emphasized that his education in the West and on American sociological literature determined his intellectual formation and helped him build a critical distance from socialism long before its collapse (cf. Županov, 1995, p. 7).

\footnotetext{
17 Along with the translation of Berger's study which passionately praised capitalism and denounced socialism, Hrvatska sveučilišna naklada (Croatian University Publisher) published the Croatian translation of Francis Fukuyama's The End of History and the Last Man in its Liberalna misao (Liberal Thought) series a year before, just two years after its original publication. Since this text celebrating the universality of the neoliberal principle after the Cold War is familiar to humanist circles, I will not be commenting on it, I simply mention its publication in Croatia as a kind of sign of the times.
} 
His affective approach to socialism in the early 1990s could be viewed in the context of triumphalist intellectual narratives of hindsight that proclaimed socialism dead, which was, after all, a general trend of both the intellectual right and the intellectual left in Europe and America after 1989 (cf. Kumar, 1992). Although critical of the new mentality being created in Croatian society in the early 1990s, Županov devoted a large portion of his book to the demystification of socialism as an economic, ideological and value system. Naturally, speaking of one system always implies thinking about its ideological counterpart. Thus in the essay entitled "Od "komunističkog pakla' do 'kapitalizma s ljudskim licem"” (“From 'Communist Hell' to 'Capitalism with a Human Face"') published in this book, Županov, giving his diagnosis on the irreversible death of socialism, claims:

As a social system [socialism] has not shown itself to be an acceptable alternative that can work at least as well as capitalism since it can never surpass it. Although some serious scientists had until recently tried to convince us that, in one form or another, socialism is even more efficient than capitalism, ... there is no point in wasting words on the subject anymore: recent developments have given us a clear and unambiguous answer to that question. Socialism did not pass the test of satisfying man's needs (from individual consumption to economic development and political freedom) and therefore it had to become history. (Županov, 1995, p. 57)

The discursive features in the author's reflections on both systems are always clearly value judgements with associated affects, and this can be inferred from a number of claims relevant to the issues discussed here. For example, in the autopsy of a self-managing project which was unsustainable according to the author because it was not realized in the market system (Županov, 1995, p. 25), Županov speaks about the negative socioeconomic theorem of Yugoslav self-management, particularly in terms of stifling the entrepreneurial initiative that spread to the transition period in the form of the inherited baggage of the so-called "egalitarian syndrome". Županov views the egalitarian syndrome or the levelling of income as an enemy of any individual creativity, including entrepreneurship (Županov, 1995, p. 30), ${ }^{18}$ while he frequently views America as a desirable economic and often democratic ideal (Županov, 1995, pp. 95, 152). As can be expected, Županov is not overly euphoric when it comes to what will follow the unpredictable transition. He anticipates a crisis of transition and is sceptical about its successful outcome. As for socialism, he regularly links

${ }_{18}$ Such thoughts on the mentality of the levelling of income which hinders the development of contemporary Croatian society, and whose roots are in socialism, have recently become the subject of polemical and critical comments. For the critique of the egalitarian syndrome in Županov, see Dolenec, 2014. 
affects which fit into the hitherto described dominant line of the "structure of feeling" of rediscovered capitalism. And for capitalism to be rediscovered, socialism had to be buried in terms of discourse, affects and morality.

In these short descriptions of instances where capitalism and socialism were analysed, with socialism lending itself as the shadow of capitalism in the texts of foreign and Croatian authors in the early 1990s, I wanted to detect and point out the value and affective code that follows theoretical considerations in the field of economic and sociological literature as the then current level of reflection on these changes in the wider field of culture. It is clear that such reflections present in the aforementioned publications had a wider social impact in terms of production and distribution of specific value judgements and affects about (nascent) capitalism and (dying) socialism. Finally, some of these examples became university textbooks as a result of the emergence of a new economic climate due to deep social changes, and the fact that the feelings and attitudes towards it disseminated and perpetuated these attitudes as a kind of norm. Regardless of the fact that these studies were sometimes significantly different in terms of the authors' approaches, just like with the examples of advertisements, they can be seen as part of the performative naturalization of the value of capitalism in the local context, resulting in the fact that capitalism in post-socialist Croatia "... emerged as the necessarily and naturally dominant form of economy and as an object of transformation that could not be transformed" (GibsonGraham, 2006, p. 198).

\section{Voices of Resistance: "Witches" and Capitalism}

Since economic culture implies heterogeneous voices of acceptance, negotiation and opposition (cf. Hall, 2006), in the last part of this paper I want to include the pattern of culture of opposition through significant intellectual voices belonging to the now canonized culture of post-Yugoslav dissidents, and to try to examine some of the thus far insufficiently explored aspects. From a wider set of texts and practices of the post-Yugoslav voices of criticism of the dominant stream of thought of the early 1990s, which would include Dubravka Ugrešić, Boris Buden, Bora Ćosić, Slavenka Drakulić, Predrag Matvejević, Mirko Kovač, Viktor Ivančić, Boris Dežulović, Predrag Lucić, Jelena Lovrić, Rada Iveković, etc., I will focus on the texts of Ugrešić and Drakulić, which I believe to be symptomatic in (among other things) how they observe the relationship between culture and capitalism in the early 1990s. Although the two authors differ significantly in their themes and approaches, and mentioning them together is practically a cliché, I cannot resist this precisely because of the specific position of the 
imagery of capitalism in their texts, which is further strengthened by the gender articulation of these problems and which can be considered specific to certain forms of harassment, or what Gibson-Graham (2006, p. xxii) call the queering of capitalism. I also believe that the shift towards gender issues within the main theme will additionally highlight the complex dynamics of the layers of moral and affective economy of culture in the observed period in which different ethnic, gender and class identities are positioned. The aforementioned authors, with their individual oeuvres and affects associated with socialism and capitalism that emerge from them, not only undermine the dominant nationalistic but also capitalist desire, creating in their texts a different moral and affective economy of post-socialism from what we detected in the dominant culture of the early 1990s. At the time of "late capitalism" (Jameson, 1988), ${ }^{19}$ both authors lived in the West, which facilitated the formation of their critical distance towards the global capitalism of the 1990s, which had until that point lured the socialist East with its desires, and at that time finally arrived in their backyard.

The authors themselves were part of the media scandal known as "the Witches from Rio", ${ }^{20}$ a series of pamphlets that defamed the authors and their colleagues on a gender, intellectual, political and ethnic basis, which, as I try to demonstrate, was structurally associated with the rise of capitalism not only in the post-Yugoslav space, but with the rise of capitalism in the historical sense. Furthermore, fictional and non-fictional texts by both authors have so far been dominantly interpreted as part of the criticism of nationalism, the condemnation of war, the revision of historical memory and the erasure of the memory of socialism in the national cultures of Eastern European countries in the early 1990s (see e.g. Biti, 2005; Lukić, 2001, 2006; D. Williams, 2013; Zlatar, 2004). Naturally, this is an important aspect of their texts, both in an affective and political sense, related to the problems discussed in this paper in various ways, but their value, as I intend to show, does not exhaust itself in that alone. I claim that the specific aspect of their criticism of capitalism is also a politically progressive part of their public activity in the 1990s (and later), which is insufficiently recognized in the interpretation and criticism of their texts. This layer has not caused much analytical attention so far, although it is extremely important and closely related to the practices of nationalism, particularly its relation to the socialist heritage as a critique of capitalism, which both authors criticize in their collections of essays published in that period. Moreover, the first collection of essays by Ugrešić published after the collapse of socialism, in

\footnotetext{
19 Since then, Ugrešić has continued to live outside Croatia permanently.

20 Along with Jelena Lovrić, Rada Iveković and Vesna Kesić. More on that at http://www.women-war-memory.org/index.php/hr/povijest/vjestice-iz-ria ("Vještice iz Ria", n.d.).
} 
which the author articulated her critical attitude towards nationalism and war on the territory of the former Yugoslavia, is entitled Američki fikcionar (American Fictionary) in which capitalism, more specifically American capitalism, is both quantitatively and qualitatively an equally important layer of the author's observations, closely related to the reflection on the war and political, social and cultural processes on post-Yugoslav territory.

American Fictionary is a book about the United States in the late capitalist period and the war in the former Yugoslavia. In that book, the United States, or simply America, the term Ugrešić uses more often, functions as a deeply rooted metaphor of the capitalist West. America, as a sign of postmodern capitalist culture in this book of essays, meets a disintegrating Yugoslavia, a country whose brutal conflict surpasses fictional imagination. In such a process, the author juxtaposes the theme of war and the postmodernist spectacle like a film editor who observes these seemingly distant but structurally closely related layers side by side (Ugrešić, 2002, p. 85). In this book, the author is particularly critical of the superficial culture of the American consumer mentality, in which spectacle, narcissism, disinterest and ignorance about the world outside America prevail, especially about the position of Eastern Europe and Yugoslavia in that imagery. She observes the features of capitalist culture at the beginning of the 1990s in an environment that is miles away from the post-Yugoslav conflict, although only a decade later they will become dominant on the local terrain as well. The author's criticism of capitalism is also expressed in an identification with economically weak subjects such as the homeless, African Americans and the Others as subjects degraded in terms of race, gender and class (Ugrešić, 2002, p. 27). Through the affects of compassion and identification with these "Others" of capitalism, what indirectly echoes is the symbolic inheritance of the moral and affective economy of the Yugoslav experience of social justice which falls into oblivion in the hegemonic culture in Croatia in the 1990s. As an addition to Ugrešić's view, I would like to mention Drakulić's essay "Komunistička perspektiva, ili što sam vidjela u New Yorku?" (“The Communist Perspective, or What Did I See in New York?") from her collection of essays Kako smo preživjeli komunizam i čak se smijali (How We Survived Communism and Even Laughed). In this essay, as well as in the whole book, the United States and the capitalist West are observed from a specific cultural perspective with a clear memory of the affective economy of Yugoslav socialism. In this essay, Drakulić develops the idea that although communism collapsed in Eastern European countries, with newly created states expelling socialism from institutional memory, the citizens of these countries still carried a specific perspective sensitive to the class inequality that the author observes precisely in contact with the American culture of developed capitalism 
(Drakulić, 2005, pp. 286-287). Thus, American capitalism is not the subject of utopian desire, and the criticism that can be read in both authors is built in dialogue with the memory of the socialist critique of capitalism which was marginalized in Croatia in the early 1990s. The problems of moral and affective economy of capitalism that Ugrešić and Drakulić refer to in their essays on the American cultural space were slowly finding their way into the local context marked by the war and the tempestuous socio-political transition even in the early 1990s, as I tried to show by analysing examples of specific "patterns of culture" associated with the practices of legitimizing capitalism from the same period. ${ }^{21}$ The polyphony of patterns of culture testifies to the heterogeneity of the field and the important role of culture not only in legitimizing, but also in examining and criticizing newly established values at the social, political and economic levels. By presenting the critique of the moral economy of American capitalism in the early transitional opus of Ugrešić and Drakulić, I wanted to show that in these authors the criticism of capitalism is inseparable from the evaluation of the collapse of socialism and the growth of nationalism, which can be interpreted as part of the critical legacy of the affective and moral economy of Yugoslav socialism that retains a reasonable scepticism towards capitalism. And it was precisely their specific memory of socialism and critique of nationalism, which was on the rise, that set them apart from the patriarchal culture of the 1990s, which labelled them with the pejorative term "witches", where their position in the hegemonic culture of the 1990s was symptomatic for the formation of a new "structure of emotions". Namely, the compromising metaphor of the witch the authors were labelled with because of their supposed disloyalty to the patriotic goals of the nation also shows a profound connection not only with nationalism but also with capitalism as closely related manifestations of patriarchy, even though the latter does not seem so obvious. However, as Silvia Federici showed in her book Caliban and the Witch: Women, the Body and Primitive Accumulation, witch hunting coincided with the historical development of capitalism in Europe, and this author recognizes this deep connection. Federici explains the link between patriarchy and capitalism in the phenomenon of witch hunting with reasons why "witch hunting was also instrumental to the construction of a new patriarchal order where women's bodies, their labour, their sexual and reproductive powers were placed under control of the state and transformed into economic resources" (Federici, 2004, p. 170). Although in the West in the early 1990s capitalism

\footnotetext{
${ }^{21}$ The authors did not renounce their (post-)Yugoslav perspectives in the later years of postYugoslav transition; moreover, they continued to explore the problems of culture and capitalism in their essays, especially Ugrešić in her books Thank You For Not Reading (2001); Nobody's Home (2005); Assault on the Minibar (2010) and Europe in Sepia (2013).
} 
had already adopted many values far removed from the traditional notion of the woman's role in society, I want to show that such values are in many ways fragile because they are at all times threatened by the spectre of patriarchy that can endanger and destroy them not only at the discursive, but also at the biopolitical level, as we can see presently at the end of the second decade of the 21 st century across Europe and the world. In this sense, by referring to this layer of capitalism, I want to avoid the anachronistic connection of the 16th and 20th centuries, but I am trying to refer to the structural and deep patriarchal features of every historical rise of capitalism, where the case of Croatia in the 1990s also fits. In the early 1990s, resisting as a woman from any position was particularly problematic. Witch hunting, whether it was understood in its specific historical or symbolic and metaphorical aspect, ${ }^{22}$ is part of the process of the domestication of women that made them economically dependent on men, and as Alex Knight claims in a review of Federici's study and which could be applied in the case of the so-called post-Yugoslav "witches" from the 1990s, “... capitalism is and has always been a male dominated system, which reduces opportunities and security for women as well as marginalizing those who don't fit within narrow gender boundaries" (Knight, 2009).

The authors mentioned here, together with their accused colleagues, did not fit in the new form of the nation-state or in the capitalist order that was being forged in the Croatian mainstream media ${ }^{23}$ which dominated the public space at that time and in which the authors and socialism as a set of specific values were subjected to a public lynching. However, from these marginalized critical voices, more powerful voices of resistance in the field of literature and culture would later arise, as part of the problem of the relationship between culture and capitalism in the later decades of postYugoslav transition, which I leave for some other occasion.

\section{On the Ruins of Yugoslav Socialism}

In this paper, I have touched upon some questions of capitalism and culture in terms of representation, distribution and circulation of economic meanings in the field of culture in the wider meaning of the term. It would

\footnotetext{
22 Although it was rarely limited to that sphere.

23 Like Globus, Večernji list, Vjesnik, Slobodna Dalmacija, Croatian Radio and Television etc. It is interesting that these authors were often labelled in the Croatian national patriarchal culture because of their literary success abroad for economic reasons, and were accused of "profiteering" on the suffering of the Croatian people and that they "sold Croatia out". It is as if female writers were not allowed to achieve financial success, or that in this case it is a morally dubious practice that requires a symbolic inquisition of the 20th century. See e.g. Maleš, 1993.
} 
be wrong to understand culture and economy as synonymous, but we can see that economic activities are always at the same time cultural, although not always the other way around (see Ray \& Sayer, 1999, p. 6). In observing various "patterns of culture" of the post-socialist "economic culture" of the early 1990s, we can recognize the processes Gibson-Graham (2006) attributed to "post-capitalist imagery", ${ }^{24}$ and here, with a lack of utopian thought, I view them as structurally close in the context of the specific postsocialist economic imagery, articulated in the field of cultural and scientific practices.

In this paper, I tried to explore the relationship between culture and capitalism when a specific economic imagery was created in Croatia as part of the post-Yugoslav territory in the 1990s, in terms that, on the one hand, an outdated system (in this case socialism) was being intellectually dismantled and, on the other hand, new economic practices of capitalism were emerging on the post-socialist terrain, with practices of opposition which, like Gibson-Graham, I consider equally important factors of "economic culture" and its polyphonic nature. All of these patterns of culture produced a new moral and affective economy of slowly rising capitalism in their own way in Croatia in the early 1990s: advertising by creating the imagery of a post-socialist consumer who wanted to satisfy his new and growing desires "quickly and easily"; a consumer who symbolically took off his work overalls and who needed to be awakened from socialist slumber and stimulated into taking the entrepreneurial initiative; economic and social thought thus had the task of creating a new post-socialist intellectual in whom socialism had to be morally and affectively delegitimized, and capitalism had to be legitimized and wholeheartedly embraced as an inevitable economic and value system that contributes to democratization and general improvement of material conditions; finally, there were voices of resistance which kept their scepticism about Western capitalism, dismantling some imagological and ideological stereotypes about the West as an economic utopia, and which preserve the memory of the moral and affective economy of socialism which was systematically delegitimized in the mainstream culture. The examples I have discussed here were selected on the basis of the colourfulness of their values and affects symptomatic for the structuring of the attitudes towards capitalism emerging from the ruins of Yugoslav socialism in the early 1990s.

24 The post-capitalist imagery according to Gibson-Graham represents a blueprint for imagining and creating new alternative economic interventions in the existing capitalist system. In their work, the two authors encourage activist confrontation with the various possibilities available in the criticism of capitalism, inventively linking political economy, feminist poststructuralism and economic activism in the field of ethical activity in modern capitalism. 


\section{References}

Ahmed, S. (2004). Affective economies. Social Text, 22(2), 117-139.

Archer, R., Duda, I., \& Stubbs, P. (Eds.). (2016). Social inequalities and discontents in Yugoslavia. London: Routledge.

Baker, C. (2010). Zvuci granice: Popularna muzika, rat i nacionalizam u Hrvatskoj posle 1991. Beograd: Biblioteka XX vek.

Banks, M. (2006). Moral economy and cultural work. Sociology, 40(3), 455-472. https:// doi.org/10.1177/0038038506063669

Bennett, T. (2005). Kultura: Znanost reformatora. Zagreb: Golden marketing Tehnička knjiga.

Berger, P. L. (1995). Kapitalistička revolucija: Pedeset postavki o blagostanju, jednakosti i slobodi. Zagreb: Naprijed.

Biti, V. (2005). Doba svjedočenja: Identitet i trauma. Zagreb: Matica hrvatska.

Bourdieu, P. (1993). The field of cultural production: Essays on art and literature. New York, NY: Columbia University Press.

Bowles, S. (2016). The moral economy: Why good incentives are no substitute for good citizens. New Haven, CT: Yale University Press.

Bowles, S., \& Edwards, R. (1991). Razumijevanje kapitalizma: Konkurencija, komanda i mijena u privredi SAD. Zagreb: Školska knjiga.

Bren, P., \& Neuburger, M. (Eds.). (2012). Communism unwrapped: Consumption in Cold War Eastern Europe. Oxford: Oxford University Press. https://doi. org/10.1093/acprof:oso/9780199827657.001.0001

Čale-Feldman, L., Prica, I., \& Senjković, R. (Eds.). (1993). Fear, death and resistance: An ethnography of war: Croatia 1991-1992. Zagreb: Institut za etnologiju i folkloristiku.

Cvek, S. (2017). Class and culture in Yugoslav factory newspapers. In D. Jelača, M. Kolanović, \& D. Lugarić (Eds.), The cultural life of capitalism in Yugoslavia: (Post)socialism and its other (pp. 101-120). New York, NY: Palgrave Macmillan. https://doi.org/10.1007/978-3-319-47482-3_6

Dimitrijević, B. (2016). Potrošeni socijalizam: Kultura, konzumerizam i društvena imaginacija u Jugoslaviji (1950-1974). Beograd: Fabrika knjiga.

Dolenec, D. (2014). Preispitivanje 'egalitarnog sindroma' Josipa Županova. Politička misao, 51(4), 41-64.

Drakulić, S. (2005). Sabrani eseji. Zagreb: Profil.

Duda, D. (2005). Literatura chorwacka w neokapitalistycznej artykulacji. In H. Janaszek-Ivaničkova (Ed.), Literatury słowiańskie po roku 1989: Nowe zjawiska, tendencje, perspektywy: Vol. 1. Transformacja (pp. 230-237). Warszawa: Elipsa.

Duda, I. (2005). U potrazi za blagostanjem: O povijesti dokolice i potrošačkog društva u Hrvatskoj 1950-ih i 1960-ih. Zagreb: Srednja Europa.

Duda, I. (2010). Pronađeno blagostanje: Svakodnevni život i potrošačka kultura u Hrvatskoj 1970-ih i 1980-ih. Zagreb: Srednja Europa. 
Elmore, B. J. (2014). Citizen coke: The making of Coca-Cola capitalism. New York, NY: W. W. Norton.

Erdei, I. (2008). Antropologija potrošnje. Beograd: Biblioteka XX vek.

Erdei, I. (2012). Čekajući Ikeu: Potrošačka kultura u postsocijalizmu i pre njega. Beograd: Srpski genealoški centar.

Federici, S. (2004). Caliban and the witch: Women, the body and primitive accumulation. New York, NY: Autonomedia.

Gajin, I. (2018). Hrvatska književnost, kultura i mediji u tranzicijskom razdoblju (Doctoral dissertation). Osijek.

Gibson-Graham, J. K. (2006). A postcapitalist politics. Minneapolis: University of Minnesota Press.

Götz, N. (2015). 'Moral economy': Its conceptual history and analytical prospects. Journal of Global Ethics, 11(2), 147-162. https://doi.org/10.1080/17449626.201 5.1054556

Gregurek, M. (2001). Stupanj i učinci privatizacije u Hrvatskoj. Ekonomski pregled, 52(1-2), 155-188.

Hall, S. (2006). Kodiranje/dekodiranje. In D. Duda (Ed.), Politika teorije, zbornik rasprava iz kulturalnih studija (pp. 127-141). Zagreb: Disput.

Hobsbawm, E. J. E. (2004). Doba ekstrema: Istorija Kratkog dvadesetog veka: 1914-1991. Beograd: Dereta.

Horkheimer, M., \& Adorno, T. (1989). Dijalektika prosvjetiteljstva. Sarajevo: Veselin Masleša and Svjetlost.

Horvat, S., \& Štiks, I. (Eds.). (2015). Welcome to the desert of post-socialism: Radical politics after Yugoslavia. London: Verso Books.

Ivanković, Ž., \& Šonje, V. (2011). Nedemokratski kapitalizam i nova tranzicija: 1. Zagrebački ekonomski forum. Zagreb: Zaklada Friedrich Ebert.

Jakovina, T. (2002). Socijalizam na američkoj pšenici. Zagreb: Matica hrvatska.

Jameson, F. (1988). Postmodernizam ili kulturna logika kasnog kapitalizma. In I. Kuvačić et al. (Eds.), Postmoderna: Nova epoha ili zabluda? (pp. 187-232). Zagreb: Naprijed.

Jelača, D., Kolanović, M., \& Lugarić, D. (2017). Introduction: Cultural capitalism the (post)Yugoslav way. In D. Jelača, M. Kolanović, \& D. Lugarić (Eds.), The cultural life of capitalism in Yugoslavia: (Post)socialism and its other (pp. 1-22). New York, NY: Palgrave Macmillan. https://doi.org/10.1007/978-3-319-47482-3_1

Knight,A.(2009). Whowerethewitches?-Patriarchalterrorandthecreationofcapitalism. Retrieved January 31, 2019, from https://endofcapitalism.com/2009/11/05/ who-were-the-witches-patriarchal-terror-and-the-creation-of-capitalism/

Kumar, K. (1992). The revolutions of 1989: Socialism, capitalism, and democracy. Theory and Society, 21(3), 309-356. https://doi.org/10.1007/BF00993452

Lakoff, G., \& Johnson, M. (2003). Metaphors we live by. Chicago, IL: The University of Chicago Press. https://doi.org/10.7208/chicago/9780226470993.001.0001

Lešaja, A. (2012). Knjigocid: Uništavanje knjiga u Hrvatskoj 1990-ih. Zagreb: Profil knjiga: Srpsko narodno vijeće. 
Lukić, J. (2001). Pisanje kao Antipolitika. Reč, 2001(64), 73-102.

Lukić, J. (2006). Imaginarne geografije egzila: Berlin i Rijeka kao fikcionalni toponimi u prozi Dubravke Ugrešić i Daše Drndić. In D. Fališevaca \& Ž. Benčić (Eds.), Čovjek, prostor, vrijeme: Književnoantropološke studije iz hrvatske književnosti (pp. 461-477). Zagreb: Disput.

Luttwak, E. (1999). Turbo-capitalism: Winners and losers in the global economy. New York, NY: Harper Collins.

Maleš, B. (1993, July 15). Kako prodati domovinu za samo sto njemačkih maraka. Slavonski magazin, 3.

Marković, L. (1991). Pogovor. In S. Bowles \& R. Edwards, Razumijevanje kapitalizma: Konkurencija, komanda i mijena u privredi SAD (pp. 393-399). Zagreb: Školska knjiga.

Matić, Đ. (2014). Tajni život pjesama: Hrvatska popularna muzika devedesetih. Zagreb: Izdanja Antibarbarus.

Morson, G. S., \& Schapiro, M. (2017). Cents and sensibility: What economics can learn from the humanities. Princeton, NJ: Princeton University Press. https://doi. org/10.1515/9781400884841

Patterson, P. (2011). Bought and sold: Living and losing the good life in socialist Yugoslavia. Ithaca, NY: Cornell University Press. https://doi.org/10.7591/ cornell/9780801450044.001.0001

Perić, I. (1992). Povijest za VIII. razred osnovne škole. Zagreb: Školska knjiga.

Perišić, R. (2002). Užas i veliki troškovi. Zagreb: Ghetaldus optika.

Povrzanović, M., \& Jambrešić Kirin, R. (Eds.). (1996). War, exile, everyday life: Cultural perspectives. Zagreb: Institute of Ethnology and Folklore Research, X-press.

Prica, I. (2004). Na tlu trivijalnog: Pismo iz tranzicije. Narodna umjetnost, 2004(41), $141-156$.

Ray, L., \& Sayer, A. (1999). Introduction. In L. Ray \& A. Sayer (Eds.), Culture and economy after the cultural turn (pp. 1-24). London: SAGE Publications. https:// doi.org/10.4135/9781446218112.n1

Richard, A., \& Rudnyckyj, D. (2009). Economies of affect. The Journal of the Royal Anthropological Institute, 15(1), 57-77. https://doi. org/10.1111/j.1467-9655.2008.01530.x

Rusinow, D. (1977). The Yugoslav experiment 1948-1974. London: C. Hurst \& Company for the Royal Institute of International Affairs.

Samuelson, P. A., \& Nordhaus, W. D. (1992). Ekonomija. Zagreb: Mate.

Scribner, C. (2003). Requiem for communism. London: The MIT Press. https://doi. org/10.7551/mitpress/5906.001.0001

Sekulić, D. (Ed.). (2016). Vrijednosti u hrvatskom društvu. Zagreb: Centar za demokraciju i pravo "Miko Tripalo".

Senjković, R. (2002). Lica društva, likovi države. Zagreb: Institut za etnologiju i folkloristiku.

Storey, J. (1998). An introduction to cultural theory and popular culture. Athens: The University of Georgia Press. 
Suvin, D. (2016). Splendour, misery and potentialities: An X-ray of socialist Yugoslavia, Leiden: Brill. https://doi.org/10.1163/9789004325210

Svašek, M. (2006). Postsocialism and the politics of emotions. In M. Svašek (Ed.), Postsocialism: Politics and emotions in Central and Eastern Europe (pp. 1-33). New York, NY: Bergham Books.

Thrift, N. (1999). Capitalism's cultural turn. In L. Ray \& A. Sayer (Eds.), Culture and economy after the cultural turn (pp. 135-161). London: SAGE Publications. https://doi.org/10.4135/9781446218112.n7

Trifonova, T. (2007). Stoned on Mars: Home and national identity in Bulgarian postcommunist cinema. Cineaste, 2007(June), 32-36.

Ugrešić, D. (2002). Američki fikcionar. Zagreb: Konzor \& Samizdat B92.

Vještice iz Ria. (n.d.). Retrieved January 31, 2019, from http://www.women-warmemory.org/index.php/hr/povijest/vjestice-iz-ria

Vučetić, R. (2012). Koka-kola socijalizam: Amerikanizacija jugoslavenske popularne kulture šezdesetih godina XX veka. Beograd: Službeni glasnik.

Vukić, F. (Ed.). (2006). Umjetnost uvjeravanja: oglašavanje u Hrvatskoj: Kulturnopovijesni prikaz razvoja od sredine 19. stoljeća do početka 21. stoljeća: Katalog izložbe održane u Muzeju za umjetnost i obrt 12.6.-16.7. 2006. Zagreb: Hrvatsko oglasni zbor.

Whiteley, S.(Ed.).(2008). Christmas, ideologyand popularculture. Edinburgh:Edinburgh University Press. https://doi.org/10.3366/edinburgh/9780748628087.001.0001

Williams, D. (2013). Writing postcommunism: Towards a literature of the East European ruins. New York, NY: Palgrave Macmillan. https://doi. org/10.1057/9781137330086

Williams, R. (1997). Culture is ordinary. In A. Gray \& J. McGuigan (Eds.), Studying culture: An introductory reader (pp. 5-14). London: Arnold.

Williams, R. (1999). Advertising: The magic system. In S. During (Ed.), The cultural studies reader (pp. 410-423). London: Routledge.

Williams, R. (2006). Analiza kulture. In D. Duda (Ed.), Politika teorije, zbornik rasprava iz kulturalnih studija (pp. 35-63). Zagreb: Disput.

Zlatar, A. (2004). Tekst, tijelo, trauma: Ogledi o suvremenoj ženskoj književnosti. Zagreb: Naklada Lijevak.

Županov, J. (1995). Poslije potopa. Zagreb: Nakladni zavod Globus. 


\section{Transformacija ekonomskog imaginarija u hrvatskoj kulturi 90-ih godina 20. stoljeća}

Članak problematizira odnos kulture i kapitalizma u kreiranju specifičnog ekonomskog imaginarija devedesetih godina $u$ hrvatskom kulturnom prostoru kao dijelu postjugoslavenskog prostora. Temeljno polazište rada jest da da različiti politički i ekonomski sustavi (kao što su socijalizam i kapitalizam) uvijek predstavljaju i određeni tip kulture. Nužno je da određen tip kulture uvede i legitimizira određene političke i ekonomske sisteme što znači da se isto tako javiti i one kulturne prakse koje će ih izazvati, propitivati i oponirati im. Analiza detektira procese intelektualne demontaže socijalizma i kreiranje nove "moralne i afektivne ekonomije" (Ahmed, Bowles) kapitalizma na postsocijalističkom terenu. Autorica se fokusira na tri "kulturna uzorka" (Williams) iz sfere konzumerističke kulture, svakodnevice, znanosti i umjetnosti koja prati simptomatične tragove u kreiranju, pregovaranju i oponiranju hegemonijskoj kulturi u nastajanju ranih devedesetih godina u Hrvatskoj.

Ključne riječi: kapitalizam, socijalizam, ekonomija, kultura, Hrvatska.

\section{Transformacja imaginarium ekonomicznego w chorwackiej kulturze lat dziewięćdziesiątych $\mathrm{XX}$ wieku}

Artykuł problematyzuje relacje między kulturą i kapitalizmem w procesie tworzenia specyficznego ekonomicznego imaginarium lat 90. w chorwackiej przestrzeni kulturowej jako części przestrzeni postjugosłowiańskiej. Głównym punktem wyjścia artykułu jest przekonanie, że różne systemy polityczne i ekonomiczne (jak np. socjalizm i kapitalizm) zawsze reprezentują określony typ kultury. Określony typ kultury jest niezbędny do wprowadzania i legitymizowania tych systemów politycznych i ekonomicznych, a jednocześnie powoduje on pojawienie się takich praktyk kulturowych, które kwestionują go i zaprzeczają mu. Analiza wykrywa procesy intelektualnego demontażu socjalizmu i tworzenia nowej „moralnej ekonomii" (Ahmed, Bowles) kapitalizmu na postsocjalistycznym terenie. Autorka skupia się na trzech „wzorcach kulturowych” (Williams) ze sfery kultury konsumpcyjnej, życia codziennego oraz nauki i sztuki, w których 
widać symptomatyczne ślady tworzenia, negocjowania i sprzeciwiania się wyłaniającej się hegemonicznej kulturze wczesnych lat 90. w Chorwacji.

Słowa kluczowe: kapitalizm, socjalizm, ekonomia, kultura, Chorwacja. Przełożył z języka chorwackiego

Tomasz Rawski

\section{Note}

Maša Kolanović, PhD., Assistant Professor at the Department of Croatian Studies, Faculty of Humanities and Social Sciences, University of Zagreb, Zagreb.

mkolanov@ffzg.hr

This paper was written as part of the project Ekonomski temelji hrvatske književnosti (The Economic Foundations of Croatian Literature) funded by the Croatian Science Foundation (IP-2016-06-2613).

No competing interests have been declared. 